Wojciech Gonet*

\title{
Zakres i formy udzielania przez jednostki samorządu terytorialnego wzajemnej pomocy finansowej - zarys problematyki
}

\section{Prawne regulacje dotyczące udzielania pomocy finansowej przez samorząd terytorialny}

Przepisy art. 10 ust. 2 u.s.g. ${ }^{1}$, art. 7a u.s.p. ${ }^{2}$ stanowią m.in., że jednostki samorządu terytorialnego (dalej: JST) poszczególnych szczebli oraz związki gmin i powiatów mogą sobie wzajemnie bądź innym JST udzielać pomocy, w tym pomocy finansowej. Natomiast przepis art. 8a u.s.w. ${ }^{3}$ stanowi, że województwa samorządowe mogą sobie wzajemnie bądź innym JST udzielać pomocy, w tym pomocy finansowej.

Pierwotny tekst ustawy o samorządzie gminnym ${ }^{4}$ nie zawierał przepisu stanowiącego o możliwości udzielania pomocy przez gminy. W 1997 r. została wprowadzona zmiana art. 10 ust. 2 ustawy o samorządzie terytorialnym przez art. 1 ustawy z dnia 22 sierpnia 1997 r. o zmianie ustawy o samorządzie terytorialnym oraz ustawy Prawo budżetowe5, ogłoszonej w dniu 9 października 1997 r., z mocą od 1 lipca 1997 r. Zmieniony przepis art. 10 ust. 2 ustawy o samorządzie terytorialnym stanowił, że gminy, związki międzygminne (związki komunalne), stowarzyszenia gmin oraz sejmiki samorządowe mogły sobie wzajemnie udzielać pomocy, w tym pomocy finansowej, w przypadku zaistnienia klęski żywiołowej, nadzwyczajnego zagrożenia środowiska, katastrof lub innych zdarzeń losowych.

* Dr Wojciech Gonet - Katedra Prawa Gospodarczego, Kolegium Zarządzania i Finansów, Szkoła Główna Handlowa w Warszawie.

1 Ustawa z dnia 8 marca 1990 r. o samorządzie gminnym, t.j. Dz. U. z 2001 r. Nr 142, poz. $1591 \mathrm{ze} z \mathrm{zm}$.

2 Ustawa z dnia 5 czerwca 1998 r. o samorządzie powiatowym, t.j. Dz. U. z 2001 r. Nr 142, poz. 1592 ze zm.

3 Ustawa z dnia 5 czerwca 1998 r. o samorządzie województwa, t.j. Dz. U. z 2001 r. Nr 142, poz. 1590 ze zm.

4 Dz. U. z 1990 r. Nr 16, poz. 95.

5 Dz. U. Nr 123, poz. 775. 
Zakres pomocy ograniczony był do sytuacji ekstremalnych. Dokonana zmiana nastąpiła w związku z powodzią, jaka w 1997 r. dotknęła Polskę , a w szczególności Dolny Śląski i dorzecza Odry. Skala zniszczeń była ogromna. Nastąpiło zniszczenie mienia osób fizycznych, przedsiębiorców, mienia samorządowego i państwowego. Pomoc była udzielana w różnej formie i przez różne podmioty. Zmiana przepisu art. 10 ust. 2 ustawy o samorządzie terytorialnym umożliwiła również zaangażowanie się w pomoc gminom, które ominął kataklizm, co świadczyło o solidarności i zrozumieniu potrzeb.

Z dniem 1 stycznia 2001 r. nastąpiło rozszerzenie zakresu przesłanek umożliwiających gminom udzielanie wzajemnej pomocy. Przepis art. 3 ust. 2 ustawy z dnia 13 października 2000 r. o zmianie ustawy o dochodach jednostek samorządu terytorialnego w latach 1999 i 2000 oraz niektórych innych ustaw ${ }^{7}$ nadał art. 10 ust. 2 ustawy o samorządzie terytorialnym następujące brzmienie: „Gminy, związki międzygminne, stowarzyszenia gmin mogą sobie wzajemnie bądź innym jednostkom samorządu terytorialnego udzielać pomocy, w tym pomocy finansowej". Przepisy art. 8 i 9 ustawy o zmianie ustawy o dochodach jednostek samorządu terytorialnego w latach 1999 i 2000 oraz niektórych innych ustaw, dodały odpowiednio art. 7a do u.s.p. i art. 8a do u.s.w. w obecnie obowiązującym brzmieniu, umożliwiające udzielanie powiatom i województwom samorządowym pomocy, w tym pomocy finansowej. Przedmiotowa zmiana, która weszła w życie od 1 stycznia 2001 r. dotycząca trzech szczebli samorządu terytorialnego, umożliwia wzajemne wspieranie się JST nie tylko - jak pierwotnie - w sytuacjach ekstremalnych, lecz właściwie w niemal każdym przypadku, gdy taka potrzeba zachodzi i znajdzie się JST, związek gmin/powiatów lub stowarzyszenie JST skłonne udzielić pomocy.

O możliwości udzielania pomocy przez JST stanowi również przepis art. 220 ust. 1 u.f.p. ${ }^{8}$ Analogiczne rozwiązania były zawarte w art. 117a ustawy z dnia 26 listopada 1998 r. o finansach publicznych ${ }^{9}$ oraz w art. 175 ustawy z dnia 30 czerwca 2005 r. o finansach publicznych ${ }^{10}$. W przepisie art. 220 ust. 1 u.f.p. mowa jest o udzielaniu pomocy z budżetu JST. Na podstawie art. 4 ust. 2 u.f.p. przepisy dotyczące JST stosuje się odpowiednio do związków gmin i powiatów, co oznacza, że art. 220 ust. 1 u.f.p. swym zakresem przedmiotowym obejmuje również związki gmin i powiatów. W literalnym brzmieniu nie obejmuje natomiast stowarzyszeń JST.

${ }^{6}$ Tak również A. Szewc, [w:] A. Szewc, G. Jyż, Z. Pławecki, Samorząd gminny. Komentarz, Warszawa 2005, s. 110.

${ }^{7}$ Dz. U. z 2000 r. Nr 95, poz. 1041.

${ }^{8}$ Ustawa z dnia 27 sierpnia 2009 r., o finansach publicznych, Dz. U. Nr 157, poz. 1240 ze zm.

9 T.j. Dz. U. z 2003 r. Nr 15 poz. 148 ze zm. - uchylona.

${ }^{10}$ Dz. U. z 2005 r. Nr 249, poz. 2104 ze zm. 


\section{Podmioty, jakim może być udzielona pomoc przez poszczególne szczeble samorządu terytorialnego}

Przepis art. 10 ust. 2 u.s.g. stanowi, że gmina może udzielić pomocy, w tym finansowej, innej JST, związkowi gminnemu, stowarzyszeniu JST, do którego należy tylko jeden szczebel samorządu terytorialnego, np. gminy lub powiaty albo jednostki ze wszystkich szczebli samorządu terytorialnego. Powołany przepis wskazuje, że gmina może udzielić pomocy powiatowi (ziemskiemu i grodzkie$\mathrm{mu}$ ) oraz województwu samorządowemu. Literalne brzmienie przepisu art. 10 ust. 2 u.s.p. nie wskazuje na możliwość udzielenia przez gminę pomocy związkowi powiatów i odwrotnie. Lukę w tym zakresie wypełnia przepis art. 4 ust. 2 u.f.p. nakazujący stosować odpowiednio przepisy dotyczące JST do związków gmin i powiatów, co $\mathrm{w}$ związku z art. 220 ust. 1 u.f.p. stanowi podstawę prawną do udzielenia pomocy przez gminę związkowi powiatów, jak i odwrotnie. Celowościowa (funkcjonalna) wykładnia również prowadzi do analogicznych konkluzji. Skoro przepis art. 10 ust. 2 u.s.g. wyraźnie stanowi, że gmina może udzielić pomocy finansowej stowarzyszeniu JST niezależnie od tego, jakiego szczebla JST są członkami tego stowarzyszenia oraz gmina może od takiego stowarzyszenia otrzymać pomoc, to nielogiczne byłoby przyjęcie wykładni, zgodnie z którą gmina nie mogłaby udzielić pomocy związkowi powiatów i od takiego związku przyjąć pomocy. Celem ustawodawcy było stworzenie rozwiązania prawnego umożliwiającego jak najszerszy zakres podmiotów, które z jednej strony mogą udzielić pomocy, a z drugiej same mogą jej oczekiwać. Tylko taki system daje określony poziom gwarancji, że w przypadku wystąpienia konieczności udzielenia wzajemnego wsparcia w sektorze samorządowym, tego wsparcia będzie mógł udzielić każdy podmiot tego sektora na rzecz każdego innego podmiotu bez względu na jego szczebel, czy też formę organizacyjno-prawną, tj. czy jest to związek gmin/powiatów lub stowarzyszenie (niezależnie od tego, jakie JST są jego członkami). Wykładnia systemowa przepisu art. 10 ust. 1 u.s.g. oraz art. 220 ust. 1 u.f.p. w związku z art. 4 ust. 2 u.f.p. również wskazuje na możliwość udzielenia przez gminę pomocy związkowi powiatów i odwrotnie.

Takim samym podmiotom jak gmina może udzielić pomocy związek międzygminny i stowarzyszenie JST. Na podstawie art. 10 ust. 2 u.s.g. gmina może otrzymać pomoc od powiatu, województwa samorządowego, innej gminy, związku międzygminnego, zarówno którego jest, jak i nie jest uczestnikiem. W piśmiennictwie i orzecznictwie wskazuje się, że gmina nie może udzielić pomocy JST z innego kraju ${ }^{11}$. Pogląd ten nie zasługuje na aprobatę. Gminy mogą być członkami międzynarodowych zrzeszeń społeczności lokalnych i regionalnych,

${ }^{11}$ K. Bandarzewski, [w:] P. Chmielnicki (red.), Komentarz do ustawy o samorzadzie gminnym, Warszawa 2004, s. 122 i powołany tam wyrok NSA z 6 maja 1998 r., sygn. akt I SA/Kr 1409/97, publikacja „Orzecznictwo w Sprawach Samorządowych” 1998, nr 3, poz. 104. 
o których mowa w art. 84a u.s.g. Nie ma przeszkód, aby gmina przyjęła pomoc, w szczególności finansową, JST z innego kraju lub międzynarodowego zrzeszenia. Przepis art. 10 ust. 2 u.s.g. w literalnym brzmieniu nie wskazuje, że wzajemna pomoc ma być udzielana pomiędzy JST tylko z Polski. Skoro gminy mogą być członkami międzynarodowych zrzeszeń społeczności lokalnych i regionalnych, to zwykle przyczyniają się do ich współfinansowania. Niewłaściwa jest wykładnia, zakładająca, że polskie JST mogą współfinansować międzynarodowe zrzeszenia samorządu terytorialnego, a nie mogłyby udzielić pomocy JST z innego kraju, gdy przyjęcie takiej pomocy przez polskie JST jest zgodne z prawem i powszechnie akceptowalne.

Podobny zakres podmiotowy udzielenia pomocy przez powiaty przewidują art. 7a u.s.p. oraz art. 220 ust. 1 u.f.p. w związku z art. 4 ust. 2 u.f.p. Oznacza to, że powiat może udzielić pomocy innemu powiatowi, gminie, województwu samorządowemu i związkowi powiatów/gmin. Powiat może również otrzymać pomoc od ww. podmiotów. Literalna wykładania przepisu art. 7a u.s.p. może być interpretowana $\mathrm{w}$ ten sposób, że powiat może udzielić pomocy i otrzymać pomoc tylko od stowarzyszeń, których członkami są jedynie powiaty. Byłaby to niewłaściwa wykładnia, sprzeczna z systemowym i celowościowym znaczeniem tego przepisu. Skoro gmina może udzielić pomocy stowarzyszeniu JST, w którym członkiem jest tylko jedna gmina, a resztę członków stanowią powiaty i województwa samorządowe oraz z takiego stowarzyszenia otrzymać pomoc, to wbrew logice byłoby dać prymat wykładni werbalnej nad wykładnią systemową oraz celowościową (funkcjonalną) i zabronić otrzymywania pomocy przez powiat od każdego stowarzyszenia JST (bez względu na skład członkowski) i udzielania pomocy przez powiat każdemu stowarzyszeniu JST. Powiat również może udzielić pomocy międzynarodowemu zrzeszeniu społeczności lokalnych i regionalnych, JST z innego kraju, a także otrzymać od tych podmiotów pomoc.

Najwęższy zakres podmiotowy spośród JST, dotyczący udzielania pomocy, zdają się mieć województwa samorządowe. Przepis art. 8a u.s.w. stanowi, że województwa samorządowe mogą sobie wzajemnie bądź innym JST udzielać pomocy, w tym pomocy finansowej. Na podstawie art. 220 ust. 1 u.f.p. w związku $\mathrm{z}$ art. 4 ust. 2 u.f.p. województwa samorządowe mogą udzielać pomocy związkom gmin/powiatów oraz mogą od tych związków otrzymywać wsparcie. Przepisy art. 8 a u.s.w., art. 220 ust. 1 u.f.p. w związku z art. 4 ust. 2 u.f.p. w literalnym brzemieniu nie wskazują na możliwość udzielenia przez województwo samorządowe pomocy stowarzyszeniu JST oraz możliwości otrzymania takiej pomocy od stowarzyszenia JST. Województwo samorządowe może tworzyć stowarzyszenia w tym z gminami i powiatami (art. 8b u.s.w.). Skoro gminy i powiaty mogą udzielać stowarzyszeniom JST pomocy i taką pomoc otrzymywać, niezależnie od tego, jakie szczeble samorządu terytorialnego tworzą te stowarzyszenia, to również województwa samorządowe w analogicznym zakresie mogą z tej pomocy korzystać 
i jej udzielać ${ }^{12}$. Wynika to z wykładani systemowej i celowościowej. Odmienna wykładnia prowadziłaby do sytuacji, że JST różnych szczebli znajdowałby się w odmiennych stanach prawnych, a w takich samych sytuacjach faktycznych. Świadczyłoby to o nierównym traktowaniu JST na różnych szczeblach. Gminy i powiaty mogłyby otrzymywać pomoc od szerszego kręgu beneficjentów, a województwa samorządowe - od węższego. To samo dotyczyłoby różnic w udzielaniu pomocy przez województwa samorządowe w porównaniu do gmin i powiatów. Byłoby to nieracjonalne. Województwo samorządowe, podobnie jak gminy, powiaty, ich związki i stowarzyszenia JST, może przyjąć pomoc od samorządu terytorialnego z innego kraju, a także od międzynarodowego zrzeszenia społeczności lokalnych i regionalnych oraz JST z innych krajów i ich zrzeszeniom udzielić pomocy.

Brak w brzmieniu art. 7a u.s.p. i w art. 8a u.s.w. sformułowania, że odpowiednio powiaty/województwa samorządowe i stowarzyszenia JST, a w art. 7a u.s.p. także sformułowania, że związki powiatów mogą sobie wzajemnie bądź innym JST udzielać pomocy, w tym finansowej, świadczy o niestaranności legislacyjnej ustawodawcy, w szczególności w sytuacji, gdy przepisy te były dodawane do u.s.p. i u.s.w. jednym aktem prawnym, tj. ustawą o zmianie ustawy o dochodach jednostek samorządu terytorialnego w latach 1999 i 2000 oraz niektórych innych ustaw.

Systemowa i celowościowa (funkcjonalna) wykładnia przepisów art. 10 ust. 2 u.s.g., art. 7a u.s.p., art. 8a u.s.w., art. 220 ust. 1 u.f.p. w związku z art. 4 ust. 2 u.f.p. wskazują, że JST bez względu na szczebel mogą sobie wzajemnie udzielać pomocy oraz analogiczna pomoc może być udzielana pomiędzy JST, związkami gmin/powiatów, stowarzyszeń JST (bez względu na to, jakie JST tworzą to stowarzyszenie), a także pomiędzy związkami gmin/powiatów i stowarzyszeniami JST bez względu na to, jakie szczeble samorządu terytorialnego są ich członkami13. Dotyczy to również możliwości otrzymania pomocy przez JST od samorządu $\mathrm{z}$ innego kraju i udzielenia takiej pomocy.

${ }^{12}$ Odmiennie, jak się zdaje, choć krytycznie do rozwiązań prawnych w tym zakresie - K. Bandarzewski, [w:] P. Chmielnicki (red.), Komentarz do ustawy o samorządzie wojewódzkim, Warszawa 2005, s. 92.

13 Odmiennie L. Lipiec-Warzecha (Ustawa o finansach publicznych. Komentarz, Wolters Kluwer Polska, Warszawa 2011, s. 999-1000), która wskazuje, że samorządowe ustawy ustrojowe, tj. u.s.g., u.s.p., u.s.w., enumeratywnie wymieniają podmioty uprawnione do otrzymania pomocy. W dalszej części tekstu będzie używany zwrot „,pomoc pomiędzy JST”, co będzie oznaczało udzielenie pomocy pomiędzy JST, JST a związkami gmin/powiatów, JST a stowarzyszeniami JST oraz związkami JST a stowarzyszeniami JST. 


\section{Przeznaczenie pomocy udzielanej przez samorząd terytorialny}

Przez pomoc należy rozumieć działania wspierające (ratunkowe) w trudnej lub niebezpiecznej sytuacji ${ }^{14}$. Do 31 grudnia 2000 r. pomoc udzielana przez gminy, związki międzygminne, stowarzyszenia gmin i sejmiki samorządowe dotyczyła sytuacji nadzwyczajnych. Od 1 stycznia 2001 r. przepisy mówiące o udzielaniu pomocy przez JST zawarte w u.s.g., u.s.p., u.s.w. oraz w kolejnych ustawach o finansach publicznych nie wskazują przykładowych sytuacji, w których może być udzielona pomoc pomiędzy JST. Nastąpiła liberalizacja przepisów w tym zakresie, co oznacza, że pomoc może być udzielona na dowolny cel ${ }^{15}$. Zgodnie z sentencją lege non distinguente nec nostrum est distenguere, jeżeli przepis ustawy jest ogólny, to nie należy wprowadzać rozróżnienia. Jest to również zgodne z historyczną ewolucją treści przepisu art. 10 ust. 2 u.s.g., który w wersji do 31 grudnia $2000 \mathrm{r}$. wskazywał na możliwość udzielenia pomocy JST w sytuacjach ekstremalnych. Zmiany treści tego przepisu od 1 stycznia $2001 \mathrm{r}$. oraz dodanie do u.s.p. i u.s.w. przepisów zezwalających powiatom i województwom samorządowym na udzielenie pomocy JST i otrzymywanie przedmiotowej pomocy, bez wskazywania na przykładowe sytuacje i cele, przesądza o tym, że pomoc może być udzielona na dowolny cel samorządowi, który jej potrzebuje ${ }^{16}$. Także przepis art. 220 ust. 1 u.f.p. nie wskazuje celów, na jakie może być udzielona pomoc przez JST, co potwierdza, że przeznaczenie środków rzeczowych i finansowych może być właściwie dowolne.

Pomoc udzielana przez JST powinna być jednak uwarunkowana wystąpieniem sytuacji, które uzasadniałyby jej udzielenie. Może być ona udzielana w sytuacji wspólnej realizacji zadań przez $\mathrm{JST}^{17}$. W takim przypadku nie będzie miało znaczenia, w jakiej kondycji są finanse lokalne JST udzielającej pomocy i JST otrzymującej pomoc.

\section{Przesłanki udzielenia pomocy finansowej przez JST}

Nie nasuwa wątpliwości możliwość udzielenia wsparcia finansowego przez JST w sytuacjach, gdy inna JST, związek gmin/powiatów, stowarzyszenie JST dotknięte zostały kataklizmem, katastrofą, klęską żywiołową itp. Pomoc finan-

${ }^{14}$ A. Szewc, [w:] A. Szewc, G. Jyż, Z. Pławecki, op. cit., s. 111.

15 Tak w stosunku do gmin: ibidem; K. Bandarzewski, [w:] P. Chmielnicki (red.), Komentarz do ustawy o samorzadzie gminnym, s. 122; K. Bandarzewski wskazuje, że dyskusyjne jest udzielenie pomocy JST w trudnej sytuacji powstałej w wyniku błędów popełnianych przez jej organy - K. Bandarzewski, [w:] P. Chmielnicki (red.), Komentarz do ustawy o samorządzie wojewódzkim, s. 93.

${ }^{16}$ Tak również WSA w Gliwicach w wyroku z 3 marca 2010 r., sygn. akt III SA/Gl 255/10, LEX nr 606772.

${ }^{17}$ L. Lipiec-Warzecha, Ustawa o finansach publicznych. Komentarz, s. 998. 
sowa może być udzielona także w sytuacji pogorszenia się stanu finansów JST. Przedmiotowe pogorszenie kondycji finansów lokalnych może nastąpić z przyczyn zewnętrznych, niezależnych od JST oraz na skutek działań organów JST. Jako przykład przyczyn zewnętrznych można wskazać upadłość/przeniesienie/likwidację przedsiębiorstwa, które było znaczącym miejscem pracy dla mieszkańców, a budżet JST zasilany był wpływami zarówno z tytułu podatków lokalnych (np. od nieruchomości), jak i udziału w podatku dochodowym od osób prawnych/ fizycznych. Nagłe zmniejszenie się dochodów własnych, które może wystąpić w trakcie roku budżetowego, może wpłynąć na trudność zachowania równowagi budżetowej, a w efekcie może doprowadzić do ograniczenia do niezbędnego minimum zakresu zadań, jakie zrealizuje JST. Udzielenie pomocy JST w takiej sytuacji przez inne JST jest możliwe. Przykładem przyczyn wewnętrznych, które doprowadziły do trudności finansowych, jest nieracjonalna gospodarka finansami przez organy JST: wykonawczy i stanowiący oraz pion podległy skarbnikowi/ głównemu księgowemu. Problemy z utratą płynności finansowej mogą wystąpić na skutek np.: finansowania zbyt wielu inwestycji za pomocą zadłużenia, nadmiernych wydatków bieżących niedostosowanych do realnych potrzeb, tj. zbyt duże zatrudnienie $\mathrm{w}$ jednostkach podległych JST i w samej JST, nazbyt rozbudowana sieć placówek oświatowych, publicznej opieki zdrowotnej, placówek kulturalno-oświatowych itp. Wymienione przyczyny trudności finansowych są przesłankami do podjęcia działań restrukturyzacyjnych. Udzielenie bezzwrotnej pomocy przez JST innej JST mającej trudności ze zrównoważeniem budżetu lub nadmiernym zadłużeniem jest możliwe i zgodne z prawem, lecz niecelowe. Udzielona pomoc finansowa, jeżeli nie będzie związana z działaniami naprawczymi, polepszy sytuację JST w roku budżetowym. Jednak bez działań naprawczych problemy będą się powtarzać w kolejnych latach. W takim przypadku udzielona pomoc finansowa nie spowoduje podstawowego efektu w postaci trwałej poprawy sytuacji finansowej JST.

Pomoc udzielana JST przez inne JST nie powinna polegać na przekazywaniu środków pieniężnych lub rzeczowych dla osiągnięcia jedynie doraźnych efektów. W wyniku jej udzielenia powinna nastąpić poprawa sytuacji finansowej JST na tyle, aby w przyszłości jednostka ta nie potrzebowała już pomocy, a ponadto, aby była gotowa do udzielenia pomocy innym JST. W przypadku udzielania pomocy przez JST, związanej z koniecznością restrukturyzacji finansów JST, pomoc ta winna mieć charakter zwrotny poprzez udzielenie pożyczki niskooprocentowanej lub nieoprocentowanej, w szczególności gdy pogorszenie się stanu finansów nastąpiło na skutek działań organów JST lub jej pracowników.

Jako przesłanki udzielenia wsparcia przez JST można wskazać m.in.:

1) sytuacje konieczności łagodzenia skutków zdarzeń nadzwyczajnych (ekstremalnych);

2) poprawę stanu finansów lokalnych, które uległy pogorszeniu bez winy JST; 
3) poprawę stanu finansów lokalnych, które uległy pogorszeniu z winy JST;

4) wspólną realizację zadań.

Pomoc określona w pkt 1)-3) ma charakter jednostronny, a pomoc określona w pkt 4) dwustronny, gdyż JST, która udzieliła pomocy na realizację jakiegoś zadania, także zwykle czerpie z tego korzyści, np. pomoc finansowa udzielona przez gminę na remont budynku stanowiącego własność powiatu, gdzie mieści się szpital. Korzyści z poprawy sytuacji lokalowej placówki zdrowia czerpią mieszkańcy całego powiatu, w tym także gminy, która udzieliła wsparcia.

\section{Realne możliwości udzielenia pomocy przez JST w przypadkach losowych}

Wzajemne wsparcie, jakiego udzielają JST na realizację wspólnych zadań, ma charakter planowy. Oznacza to, że w budżecie JST, w odpowiedniej podziałce klasyfikacji budżetowej są przewidziane środki finansowe na wydatek, gdy JST udziela dotacji, darowizny, lub też rozchód, gdy JST udziela oprocentowanej lub nieoprocentowanej pożyczki. JST, która spodziewa się otrzymać pomoc finansową na wspólną realizację jakiegoś zadania, co do zasady tę pomoc otrzyma, o ile JST udzielająca pomocy sama nie znajdzie się w trudnej sytuacji finansowej.

Inaczej jest $\mathrm{w}$ przypadku pomocy, która ma łagodzić skutki zdarzeń nadzwyczajnych, czy też poprawić stan finansów JST, niezależnie od tego, z jakiej przyczyny doszło do jego pogorszenia. Zwykle JST w budżetach, a związki samorządowe w planach finansowych nie przewidują kwot na takie cele. Analogicznie jest w stowarzyszeniach JST. Jeżeli dojdzie do zdarzeń losowych, które wyrządziły szkody w JST, jednostki, które będą chciały udzielić pomocy, z braku zaplanowanych na ten cel środków w budżecie, będą mogły w tym celu wykorzystać rezerwę ogólną oraz celową, o ile zostanie utworzona.

Przepis art. 222 ust. 1 u.f.p. stanowi, że w budżecie JST tworzy się rezerwę ogólną w wysokości nie niższej niż $0,1 \%$ i nie wyższej niż $1 \%$ wydatków budżetu. Utworzenie rezerwy ogólnej w JST jest obowiązkowe, a celowej - fakultatywne, chyba że obowiązek jej utworzenia wynika z odrębnych przepisów ${ }^{18}$. Podstawą utworzenia rezerwy celowej na ewentualną pomoc dla innych JST, jest przepis art. 222 ust. 2 pkt 1 u.f.p., który przewiduje możliwość tworzenia rezerwy na wydatki, których szczegółowy podział na pozycje klasyfikacji budżetowej nie może być dokonany w okresie opracowywania budżetu JST. Pomoc udzielana pomiędzy JST ma zwykle postać dotacji. Dotacja może być udzielona zarówno na realizację zadania bieżącego, np. udzielenie zapomóg dla mieszkańców dotkniętej kataklizmem JST, jak i na realizację zadania inwestycyjnego, np. odtworzenie zniszczonej infrastruktury. W okresie opracowywania budżetu nie można określić

${ }^{18}$ L. Lipiec-Warzecha, Ustawa o finansach publicznych. Komentarz, s. 1014-1015. 
szczegółowego podziału tych dotacji czy też ewentualnie darowizn w klasyfikacji budżetowej. Wysokość rezerw celowych, których nie można dokonać klasyfikacji w okresie opracowywania budżetu wraz z rezerwami wynikającymi z innych ustaw, np. z ustawy z dnia 26 kwietnia 2007 r. o zarządzaniu kryzysowym ${ }^{19}$, nie może przekroczyć 5\% wydatków JST (art. 222 ust. 3 u.f.p.). Zarówno rezerwą ogólną, jak i celową dysponuje organ wykonawczy JST (art. 222 ust. 4 u.f.p.). Rezerwa ogólna może być zawsze przeznaczona na udzielenie pomocy innej JST (a contrario z przepisu art. 259 ust. 3 u.f.p.), a rezerwa celowa wtedy, gdy była tworzona z zamiarem przeznaczenia jej na udzielenie pomocy JST (art. 259 ust. 1 u.f.p.). Gdy rezerwa celowa była utworzona z zamiarem innego przeznaczenia, jej zamiana na pomoc dla JST może nastąpić po uzyskaniu pozytywnej opinii komisji właściwej do spraw budżetu organu stanowiącego JST (art. 259 ust. 2 u.f.p.).

Poza rezerwami ogólną i celową na pomoc dla innych JST, jeżeli na ten cel nie było przewidzianych środków w budżecie/planie finansowym, organ wykonawczy może wykorzystać instytucję zmian w planie dochodów i wydatków budżetu JST, określoną w art. 257 pkt 1 i 3 u.f.p., umożliwiającą przeznaczenie wydatków na pomoc dla JST. Ponadto, organ wykonawczy może być upoważniony przez organ stanowiący JST do dokonywania innych zmian w planie wydatków z wyłączeniem przeniesień wydatków pomiędzy działami (art. 258 ust. 1 pkt 1 u.f.p.). Jeżeli i te działania okazałyby się nieskuteczne, w celu znalezienia środków na udzielenie pomocy dla innej JST, może jeszcze nastąpić zmiana uchwały budżetowej, której dokonuje organ stanowiący.

Wykorzystanie rezerw ogólnej i celowej oraz środków pochodzących ze zmian w budżecie nie gwarantuje, że JST znajdująca się w potrzebie uzyska satysfakcjonującą pomoc bezzwrotną, nawet jeżeli przedmiotowe zmiany wprowadzi wiele JST oraz/lub przekaże na ten cel rezerwy. Wysokość rezerw jest zdeterminowana wysokością wydatków. Zmiany, jakie może wprowadzić w budżecie organ wykonawczy i stanowiący, celem udzielenia pomocy innej JST, również są ograniczone do kwot, które będą możliwe do zaoszczędzenia. Oznacza to w praktyce, że kwoty, jakie zostaną przekazane na pomoc JST, w ramach zmian w budżecie oraz z wykorzystaniem rezerw ogólnych i celowych mogą okazać się symbolicznymi w stosunku do potrzeb. Ponadto, w JST może wystąpić opór przed udzielaniem pomocy JST z innych regionów. Udzieleniem pomocy mogą być zainteresowane JST położone najbliżej, które nie zostały dotknięte nadzwyczajnym kataklizmem lub w znacznie mniejszym stopniu.

Pomoc, jakiej mogą sobie wzajemnie udzielić JST w celu łagodzenia skutków negatywnych nadzwyczajnych zdarzeń, tj. wszelkich postaci kataklizmów, może być skuteczna, szybka i znaczna pod względem finansowym w stosunku do rozmiarów strat, jeżeli JST będą regularnie i nieprzerwanie gromadzić środki

${ }^{19}$ Dz. U. Nr 89, poz. 590 ze zm.; L. Lipiec-Warzecha, Ustawa o finansach publicznych. Komentarz, s. 1016. 
finansowe na ten cel. Występowanie dość cyklicznie w Polsce fatalnych w skutkach kataklizmów naturalnych stało się faktem. Co jakiś czas poszczególne obszary kraju nawiedzane są przez powodzie, huragany, trąby powietrzne, susze itp. Zazwyczaj w tych sytuacjach uwidacznia się brak środków na udzielenie niezwłocznej pomocy dla ludności, która straciła cały swój majątek lub jego znaczną część, a w dalszej kolejności dla samej JST. Uruchomienie środków z rezerwy budżetu państwa dotychczas nie rozwiązywało problemów, a była to jedynie przysłowiowa kropla w morzu w stosunku do skali potrzeb.

Do udzielenia pomocy JST można wykorzystać związki gmin/powiatów lub/ oraz stowarzyszenia JST, mające ogólnopolski zasięg działania. W tym celu JST wszystkich szczebli mogą dokonywać wpłaty dotacji raz na rok (lub częściej) do jednego wybranego związku JST lub stowarzyszenia JST w wysokości, która byłaby ułamkiem dochodów, wydatków czy też innej określonej przez JST wielkości budżetowej. Regularnie gromadzone w ten sposób środki finansowe byłyby wykorzystywane na udzielenie pomocy JST, które zostałyby dotknięte kataklizmem. Byłoby wskazane, aby wszystkie JST przekazywały dotacje do związku gmin/powiatów lub stowarzyszenia JST na udzielenie pomocy. Przynależność do tego systemu pomocy byłaby dobrowolna, co nie oznacza, że z tej pomocy mogłyby korzystać tylko JST dokonujące wpłat dotacji (składek). Nie ma przeszkód, aby regulamin udzielania pomocy przewidywał, że ze zgromadzonych środków może być udzielona pomoc także JST, które nie wpłacają dotacji. Wysokość rocznych wpłat określona byłaby regulaminem udzielania pomocy lub też zarządzeniem/uchwałą organu wykonawczego stowarzyszenia JST/związku gmin/ powiatów. Kwota, jaką wpłacałaby JST, powinna być na tyle duża, aby środki zgromadzone $\mathrm{w}$ okresie kilkuletnim wystarczyły na udzielenie znacznej pomocy JST w sytuacji kataklizmów, np. jakie dotknęły w 2010 r. regiony południowej i środkowej Polski w czasie powodzi majowej i czerwcowej. Jednocześnie kwota ta nie może stanowić znacznego obciążenia dla budżetu. Bardziej zasadne byłoby umiejscowienie tego systemu pomocy JST w stowarzyszeniu JST, a nie w związku gmin/powiatów, ze względu na bardziej elastyczne zasady wykonania planu finansowego w stowarzyszeniach. Do planu finansowego związków gmin/ powiatów stosuje się odpowiednio przepisy dotyczące budżetu JST, co oznacza formalizm dysponowania środkami publicznymi. W przypadku stowarzyszeń JST łatwiej byłoby dysponować zgromadzonymi środkami w przypadkach, w których nie przewidziano na etapie tworzenia systemu wzajemnego wsparcia JST, a udzielenie pomocy byłoby obiektywnie zasadne. Regulamin funkcjonowania systemu pomocy powinien być elastyczny zarówno pod względem wpłat, jak i wypłat z niego. W szczególności JST, która została dotknięta kataklizmem, poza tym, że otrzymałaby dotacje na usunięcie ich skutków, to przez kilka lat byłaby zwolniona $\mathrm{z}$ wpłat do systemu wzajemnego wsparcia JST umiejscowionego w stowarzyszeniu JST lub związku gmin/powiatów. Regulamin powinien także przewidywać zawieszenie wpłat przez JST w przypadku, gdy w minionych latach 
nie dokonywano wypłat i środki systematycznie powiększały się, osiągając bezpieczny, wysoki poziom. Nie byłoby celowe gromadzenie nadmiernych środków finansowych na ewentualną okoliczność przyszłych nadzwyczajnych katastrof. Przekazywanie środków finansowych przez JST w formie dotacji do systemu pomocy umiejscowionego w stowarzyszeniu JST lub związku gmin/powiatów następowałoby na podstawie umowy zawartej na czas określony lub nieokreślony. Obecne przepisy u.f.p. i ustaw ustrojowych umożliwiają takie rozwiązanie jako przykład inicjatywy oddolnej.

\section{Podsumowanie}

Podjęcie przez JST bardziej skoordynowanych działań w celu skutecznej możliwości udzielenia pomocy wzajemnej przez JST nie wymaga wprowadzania zmian legislacyjnych. Konieczne jest rozpropagowanie tej idei wśród wszystkich JST. Zwiększyłoby się również znaczenie stowarzyszenia JST czy też związku gmin/powiatów, do którego JST wpłacałyby dotacje na pomoc dla innych JST. Stowarzyszenia JST i związki gmin/powiatów nie odgrywają większej roli jako reprezentacje samorządu terytorialnego. Utrzymywane są najczęściej ze środków JST, a ich działanie dość często sprowadza się do organizacji dorocznego zjazdu i wystosowania apeli/petycji do rządu.

Zaletą proponowanego rozwiązania byłaby anonimowość środków, z których udzielano by pomocy, szeroki krąg beneficjentów oraz możliwość przekazania dotacji w wysokości, która powinna pokryć znaczną część wydatków bieżących i inwestycyjnych, jakie trzeba ponieść w związku ze stratami. Ponadto, JST dotknięte negatywnymi zdarzeniami losowymi mogłyby korzystać ze zgromadzonych środków - w miarę ich posiadania przez stowarzyszenie/związek - w okresie kilkuletnim, a nie tylko w roku, w którym dotknął ich kataklizm. Zakres udzielanej pomocy finansowej powinien ograniczyć się do wystąpienia stanu klęski żywiołowej, nadzwyczajnego zagrożenia środowiska, katastrof lub innych zdarzeń losowych. Ponadto, pomoc byłaby udzielana także na zapobieżenie skutkom przedmiotowych zdarzeń, tj. minimalizacji ryzyka ich ewentualnych negatywnych skutków. Nie od każdego zdarzenia losowego można się skutecznie ubezpieczyć w takim stopniu, że gdy wystąpią straty, towarzystwo ubezpieczające bez zbędnej zwłoki w całości je pokryje. Otworzony przez JST dobrowolny fundusz, po kilku latach funkcjonowania i wnoszenia do niego regularnych wpłat, mógłby odegrać przedmiotową rolę. 